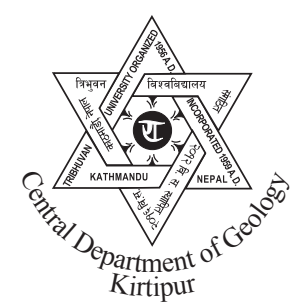

\title{
Toppling and wedge failures in Malekhu River area, Malekhu, Central Nepal Lesser Himalaya
}

\author{
*Naresh Kazi Tamrakar, Jaya Laxmi Singh, Krishna Kumar Bista and Prayag Maharjan \\ Central Department of Geology, Tribhuvan University, Kathmandu, Nepal
}

\begin{abstract}
A huge landslide was identified on the right bank of the Malekhu River at about $1 \mathrm{~km}$ upstream from the Malekhu Bridge of the Prithvi Highway, and was named Malekhu Landslide. The landslide area consists of quartzite with sericite partings, chlorite schist and amphibolite of the Robang Formation of the Kathmandu Complex. The landslide extends for about $200 \mathrm{~m}$ along the river bank slope and its crown and toe have elevation respectively of $429 \mathrm{~m}$ and $361 \mathrm{~m}$ a.s.1. The major portion of the hillslope has been altered by landsliding as evidenced from the different geometry of slopes consisting of very steep scarp slope, steep to moderate slope with toppled and wedge failure debris, and several wedges and gullies. The right-side up layers have an average dip direction of $167^{\circ}$ and a plunge of $56-90^{\circ}$, whereas the overturned layers have an average dip direction and plunge of $316^{\circ} / 32^{\circ}$. The direction towards which the toppling had occurred is $167^{\circ}$. The overturned layers had rotated to $36^{\circ}$, during which the layer dip direction had rotated counterclockwise to an amount of $31^{\circ}$ from the major direction of toppling, and this rotation should have occurred during sliding of the toppled block. The Malekhu Landslide is a complex landslide experiencing more than one mode of failure of which the most prominent one is the toppling. It is a kind of flexural toppling of passive mode and had already occurred and now is suspended. The second mode of failure is the wedge sliding. The kinematic analysis of discontinuities on the slope for evaluating possibility of landsliding has indicated that the wedge failure is potential due to the presence of a line of intersection produced by the discontinuity parallel to the foliation of the right-side up layers and the overturned layers. This suggests that the toppled blocks may further slide. It is required to protect the slope from landsliding as there have been extended two unpaved roads one along the crown and the other along the toe of the landslide, and due to existence of the Malekhu Bridge in the downstream stretch of the river.
\end{abstract}

Key words: Landslide, wedge failure, toppling, Malekhu River, Central Nepal Lesser Himalaya

Received: 18 April, 2013

Accepted: 8 July, 2013

\section{INTRODUCTION}

The Malekhu Landslide is a complex landslide located on the right bank of the Malekhu River at about $1 \mathrm{~km}$ upstream from the Malekhu Bridge (Fig. 1). The landslide area is composed of metamorphic rocks of quartzite, schist and amphibolite of the Robang Formation (Stocklin, 1981). The aerial extent of the length of the landslide approaches about $200 \mathrm{~m}$. The crown is located at elevation of about $429 \mathrm{~m}$, whereas the toe is at $361 \mathrm{~m}$ a.m.s.l.. The toppling failure is historic while the wedge failure is still active and is ongoing. Similar, toppling structure was

\footnotetext{
*Corresponding author:

E-mail address: ntamrakar@hotmail.com
}

reported by Tamrakar et al. (1999) and Tamrakar and Yokota (2008) from the Sub-Himalaya of Nepal. Both the crown and toe of the landslide are extended by separate unpaved roads which link remote villages to the town of Malekhu. The crown portion shows several small active scars and cracks and even the uphill side slope of the road extending along the crown shows small wedge failures. As more wedge failures become active, the road will be put into the risk. Secondly, the river toe erosion during high flow period also aggravates situation after river eroding the debris of the toe.

This paper presents results of detail geomorphological and geological mapping of the landslide, hereafter termed 'Malekhu Landslide'. The 1:500 scale map was prepared 


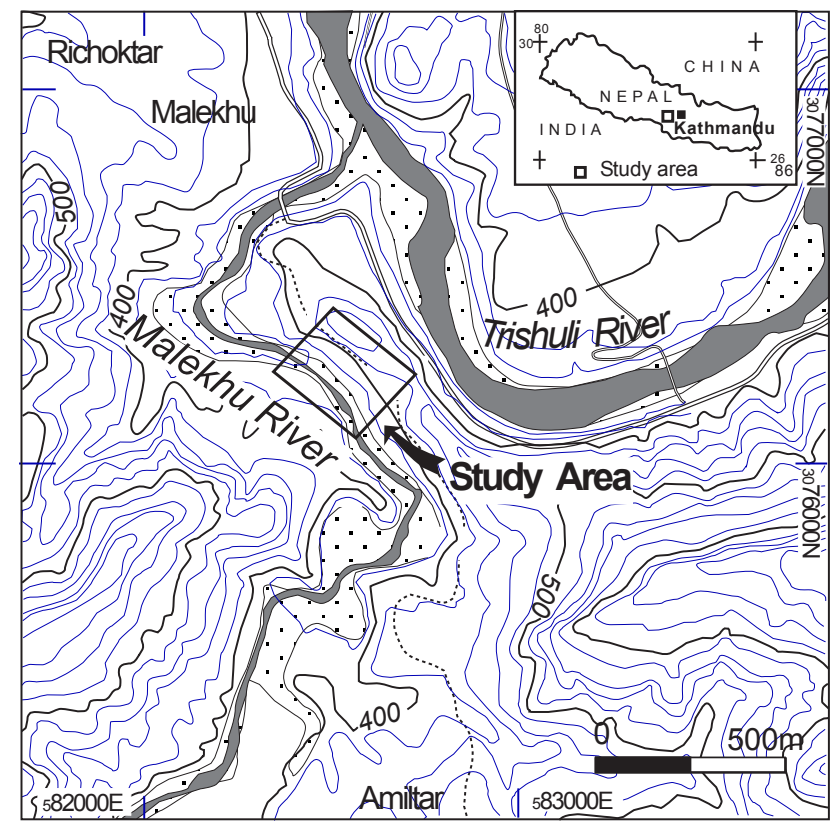

Fig. 1 Location map of tne stuay area.

by leveling survey. The geological mapping was conducted on the same scale, simultaneously, and during later phase after topographic mapping. Kinematic analysis of slope was applied to determine potential failure types. Besides, the toppled beds and right side-up beds of the slopes were measured for reconstructing the direction and amount of rotation of beds during toppling.

\section{GEOLOGICAL SETTING}

The landslide area is located in the Lesser Himalayan terrain dissected by NW-flowing river and is characterized by steep SW to S-facing dip slopes (Figs. 1 and 2). The climate of the region is warm humid. The annual temperature is around 20 degrees. The annual precipitation is around. June-August are the period of maximum amount of precipitation. The bedrocks of the Malekhu Landslide belongs to the Cambrian Robang Formation, which is the uppermost formation of the Upper Nawakot Group (Stöcklin and Bhattarai, 1977; Stöcklin, 1981). The latter belongs to the Nawakot Complex. The Robang Formation has a transitional lower boundary with the Malekhu Formation consisting mainly of dolomite, and an upper boundary with the Raduwa Formation (mainly garnetiferous schist) of the Bhimphedi Group of the Kathmandu Complex, showing a tectonic boundary, well known as the Mahabharat Thrust (Fig. 2). The Robang Formation crops out on the both banks of the Malekhu Khola about $600 \mathrm{~m}$ south from the Malekhu Bridge with attitude: $80^{\circ} \mathrm{E} / 85^{\circ} \mathrm{SE}$. Mainly the rocks of the lower part of the Robang Formation are exposed in the landslide area and these include sericite quartzite, chlorite schist, phyllite and amphibolite. Some beds are also overturned in the landslide slope. Quartzite is massive, thick bedded and yellowish white. Amphibolites are foliated and associated with quartzite. The uppermost part of the formation which lies beyond (or southward) the landslide area, is composed of a ridge forming Dunga Quartzite Member. The thickness of the Robang Formation is about $950 \mathrm{~m}$.

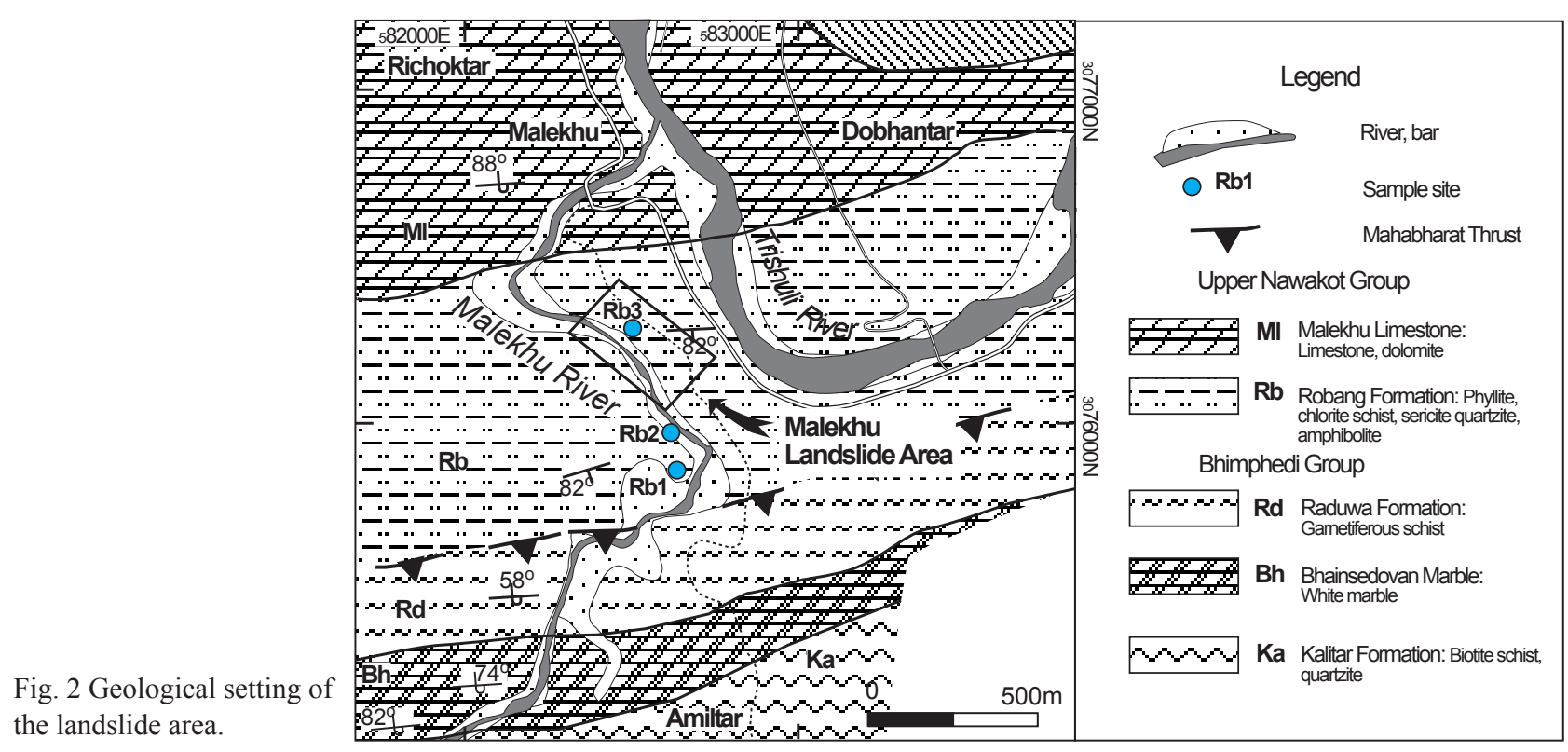




\section{GEOMORPHOLOGY}

A huge landslide occurs at the right bank slopes of the Malekhu River (Fig. 3), and is named Malekhu Landslide. The landslide area shows two distinct slopes; an original hillslope and ana altered hillslope. The former is characterized by original topography in the sense that it has not been actively involved in erosion and slope movement, and therefore contains convex type of slope with well vegetation. The altered slope is characterized mainly by very steep rocky slope with scarp and the portion of the cut slope on the uphill side of the road. The eastern portion of the landslide area containing such slope is of passive scars. The portion of the very steep scarp slope in the central portion of the area is the main scarp (Elv. $390 \mathrm{~m}$ to $428 \mathrm{~m}$ ) (Figs. 3 and 4). The crown and tow are located at Elv. of about $429 \mathrm{~m}$ and $361 \mathrm{~m}$, respectively. A numerous wedge failures occurring from this slope towards downslope (Fig. 4). The major portion of the altered slope is occupied by steep slope in which both wedge failure and topple failure have occurred. The eastern portion of the landslide area containing very steep to steep slope however contains no topping and wedge failures, but gully erosion is prominent there. Gullies there are of $5-10 \mathrm{~m}$ wide and $3-5 \mathrm{~m}$ depth.

Apart from the hillslope, the river bank slopes are important elements (Fig. 4). These contain an upper bank slope with relative height $>3 \mathrm{~m}$ and the lower bank slope with relative height $<3 \mathrm{~m}$. These slopes contain mainly alluvial sediments ranging in size from boulder to clay. The channel element consists of river point bar and mid channel bars containing huge boulders to sand.

\section{LITHOLOGY}

Distribution of llithology in the landslide area can be categorized into soil and rock. Rock is in situ mass with discontinuities, whereas soils are loose material of fragmentsof rocks.

The soil mass in the original hillslope and that of the altered slope in the eastern portion of the landslide area are mostly of residual type showing light yellow to brown yellow. Soil distributed in the central portion of the landslide area contains rubbles to clay particles and are derived from the wedge failure of the rock lying upslope. The soil exhibits angular newly broken fragments. The alluvial soil which are of varied composition (containing only only of the rock type of the landslide area but of the rock types of the area lying upstream of the river) and rounded texture occupy in the river bank slopes and channel elements. The size range from mega boulders to clay, but often dominant is the cobble and pebbles.

The whole landslide area is characterized by three rock types which extend northeast-southwest and dip southeast, but some beds are overturned to northwest (Fig. 5):

(1) The NW portion of the landslide area containing light green quartzite with sericite partings. The quartzites are thin to medium bedded, white, and are interbanded with light green grey sericite partings of up to a millimeter thickness.
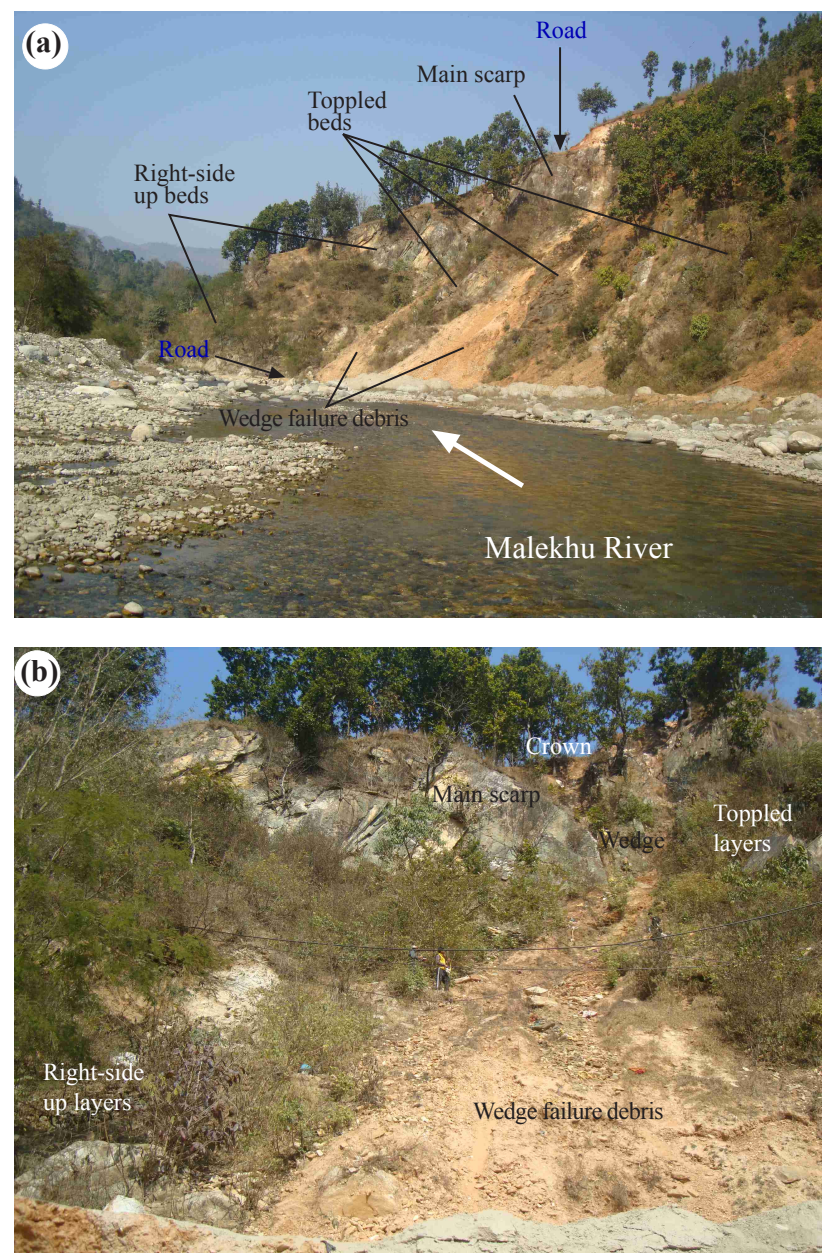

Fig. 3 (a) Landslide at the right bank of the Malekhu River; a downstream view of the river and the landslide, and (b) A closer frontal view of the Malekhu Landslide; the upper central portion occupied by the main scarp, above which is a crown along which a gravel road extends; the middle portion of the photograph is a wedge failure debris and toe of the filure. 


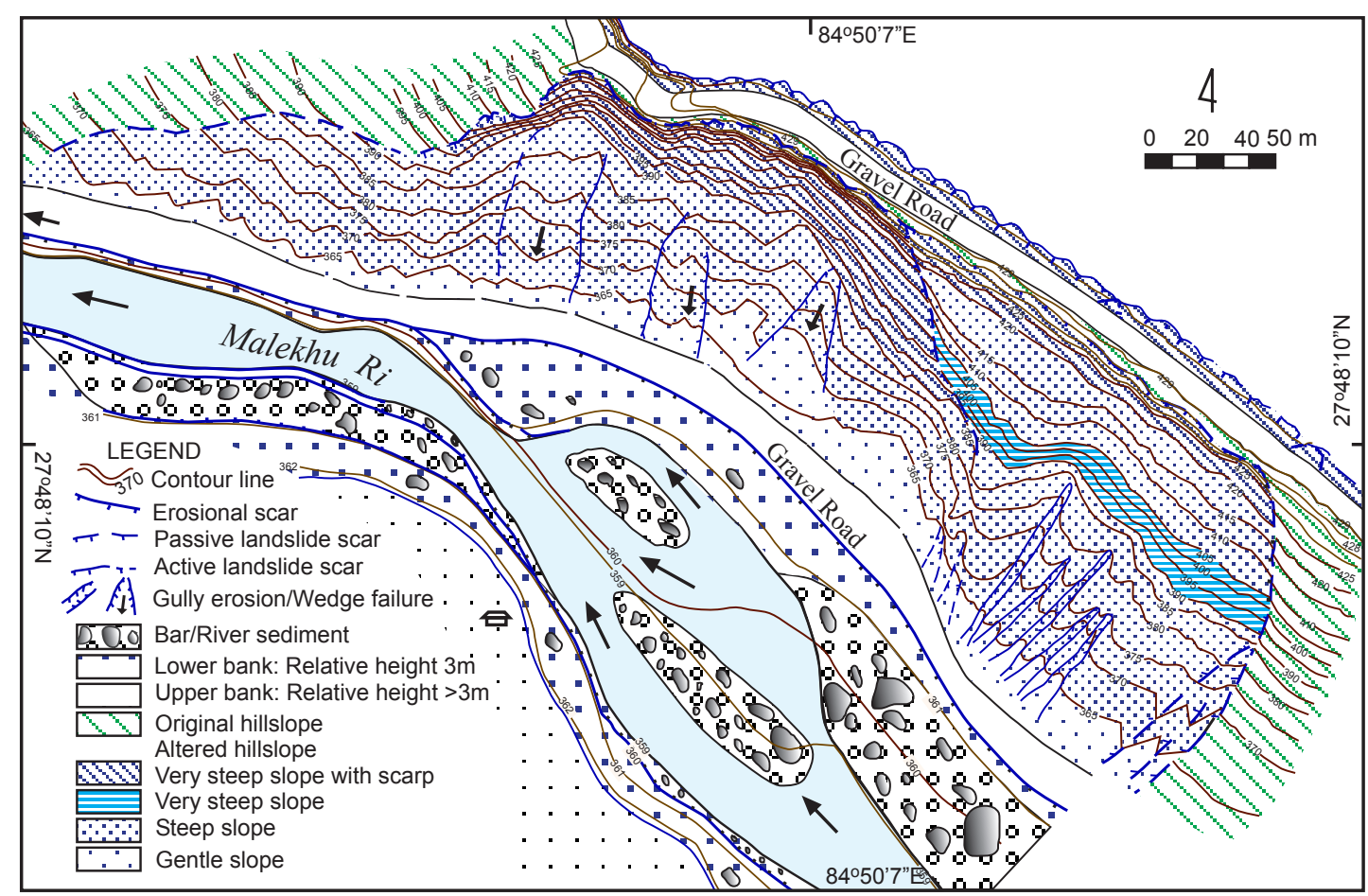

Fig. 4 Geomorphology of the landslide area.

(2) The central portion of the landslide area containing mainly the highly foliated green grey chlorite schist and few interlayering and/or isolated lenses of quartze veins, and

(3) The SE portion of the landslide area contining mainly amphibolite, amphibole schist, and quartzite.

\section{LANDSLIDE STRUCTURE}

The Malekhu Landslide is characterized by two major types of failures (Figs. 5 and 6); toppling and sliding, and wedge failure. The former is a prominent structure, the remnant of which has remained on the hillslope. The wedge failure is observed by its geometry on the outcrop and the debris it has yielded.

\section{Topple Structures}

Two toppling areas have been identified; one in the central portion of the landslide area, and the another one is slightly in the eastern portion (Fig. 5). Rock mass of quartzite, chlorite schist and amphibolite all have experienced toppling and sliding. The major lithology affected by toppling in the central portion of the landslide area consists of the chlorite schist and subordinately quartzite. In the western portion of this large toppling, the quartzite beds are mostly affected and are toppled at Elv. $370-380 \mathrm{~m}$. The attitude after toppling is about $80^{\circ}$ dipping towards NW. Whereas, the rest of the beds lying upslope and downslope are in right side up condition, and dip around $80^{\circ}$ towards SE. The crown occurs at Elv. 429 m, whereas the top of the hill is at Elv. around $450 \mathrm{~m}$. The chlorite schist constitutes the major portion of the large toppling in the central portion of the landslide area (Figs. 5 and 6). They are rotated to various degrees and have now the dip amount ranging from 55 to $80^{\circ}$. The beds which are affected by toppling lies mostly between Elv. 365 and $405 \mathrm{~m}$.

The smaller portion of toppling occurs in Elv. between 365 and $290 \mathrm{~m}$, in the eastern portion of the landslide area, and here the rocks are composed mainly of amphibolite, amphibole schist and subordinately of quartzite. The overturned beds show 60 to $70^{\circ}$ of dip amount towards NW.

\section{Wedge Structures}

In the central portion of the Malekhu Landslide, three prominent wedge failures have been identified. These wedges have occurred due to favouring condition of intersection of joints thus forming potential wedges. The wedge failure debris accumulates downslope and exhibits 


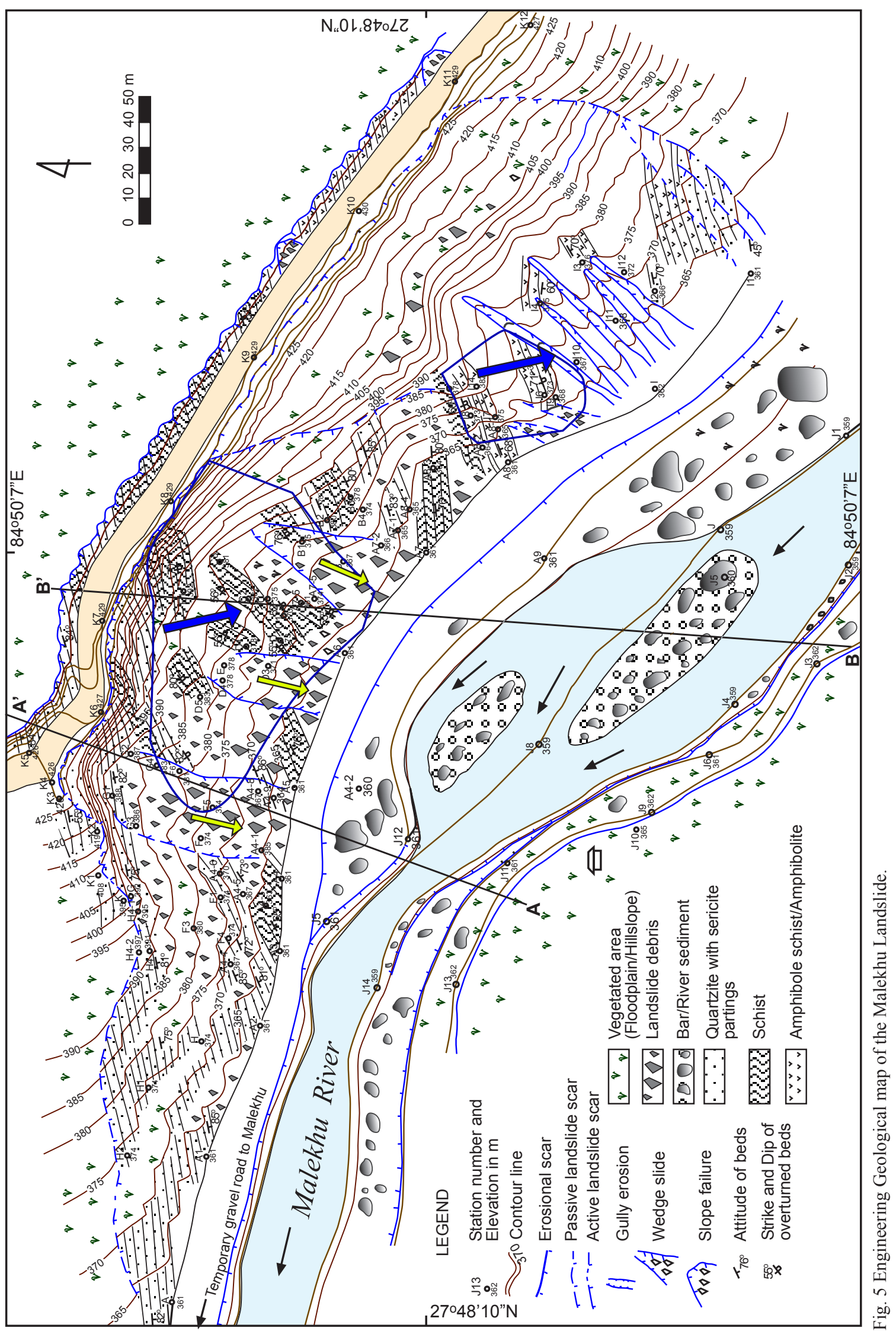


(a)
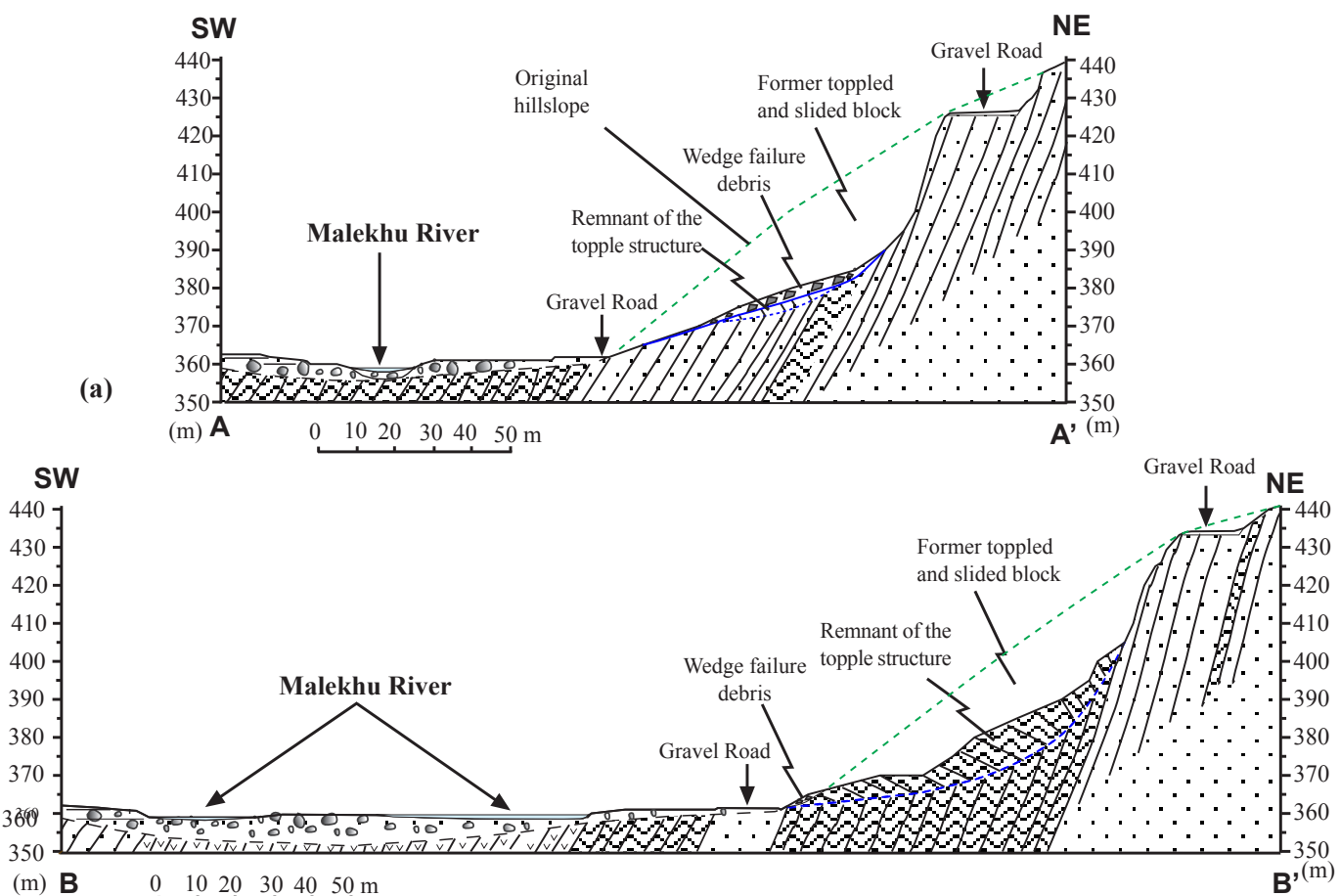

Fig. 6 Cross-sections of the topple structure: (a) The section along the line A-A', and (b) The section along the line B-B'.

rubbles of more than a meter to gravel sized. The wedge failure is active and is on going.

\section{MECHANISM OF LANDSLIDING}

\section{Toppling}

The beds distributed in the Malekhu Landslide were measured and analysed for their attitudes to reconstruct the mechanism of landslide phenomenon and the geometrical configuration of rotation of beds through toppling (Figs. 6 and 7). The following are the configuration of the beds:

(a) Right-side up beds (hereafter normal beds): The mean azimuth of the normal beds is $167^{\circ}$ (with a range $143^{\circ}-196^{\circ}$ ). The range of dip of normal beds is $56^{\circ}-90^{\circ}$. The attitude of the pole maximum of the normal bed is $167^{\circ} / 86^{\circ}$.

(b) Overturned beds (toppled beds): The mean azimuth of the overturned beds is $316^{\circ}$ (the range being $\left.292^{\circ}-355^{\circ}\right)$. The attitude of pole maximum of the overturned beds is $316^{\circ} / 32^{\circ}$.

The overturned beds are found to have rotated (change in plunge) from the normal poisition to the total amount of $36^{\circ}$. The bed dip direction had rotated counterclockwise to an amount of $31^{\circ}$ from the major direction of toppling to $167^{\circ}$. This rotation probably had occured during sliding. The nature of toppling is described as a flexure toppling of passive mode, in which rocks fail either due to tensile bending stresses upon most probably dynamic loading, since the inclination of layers of rock is greater than the slope angle (Aydan and Amini, 2009). This toppling is different from that of the active mode in which tensile bending stresses of layers occur and some overturn under their own weights (Goodman and Bray, 1976; Goodman, 1989; Majdi and Amini, 2011).

The kinematic analysis for toppling using the Markland's (1972) criteria, exhibits that there is no further possiblity of toppling failure (Fig. 8).

\section{Wedge failure}

The wedge sliding Kinematic analysis (Fig. 9) shows that there is a potential intersection between the normal beds and the overturned beds, after using Markland's (1972) criteria. Other intersections do not form potential wedges. The presence of a potential wedge indicates that sliding of the toppled mass possibly occurs towards SW, and also had occurred in the past also thus depleting the toppled rock mass of the original hillslope (Fig. 5). 


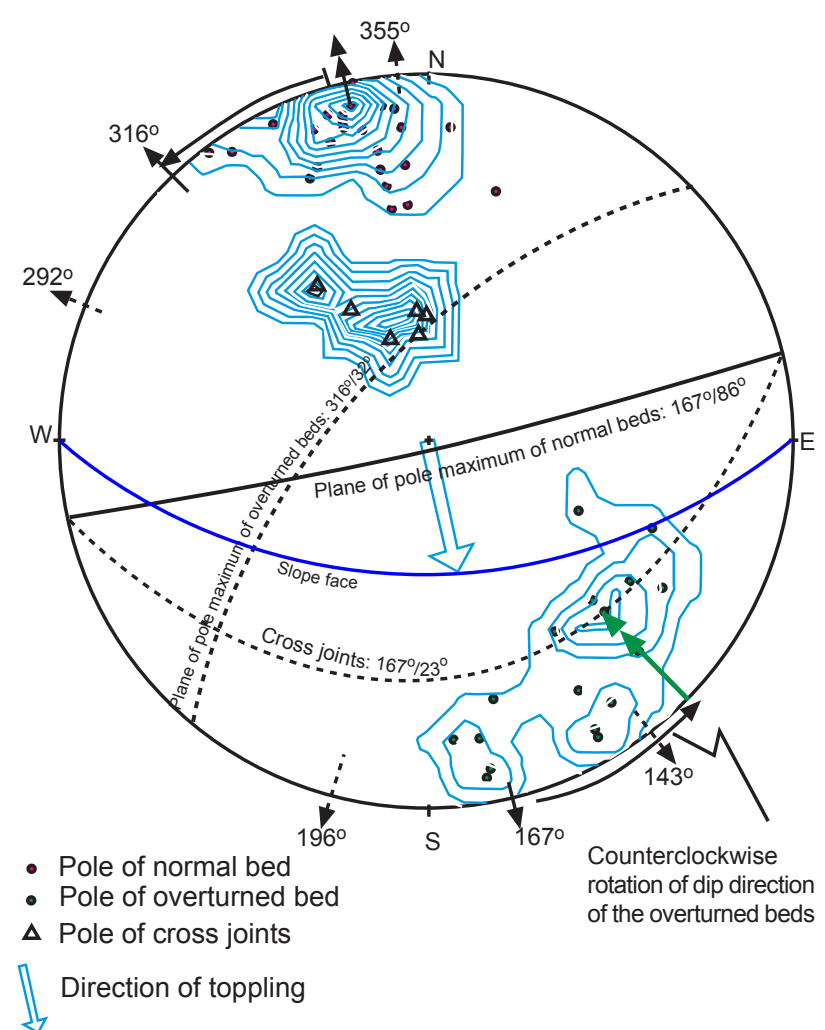

Fig. 7. Stereographic projection of poles of normal and overturned beds from the landslide area showing the direction and amount of rotation of beds.

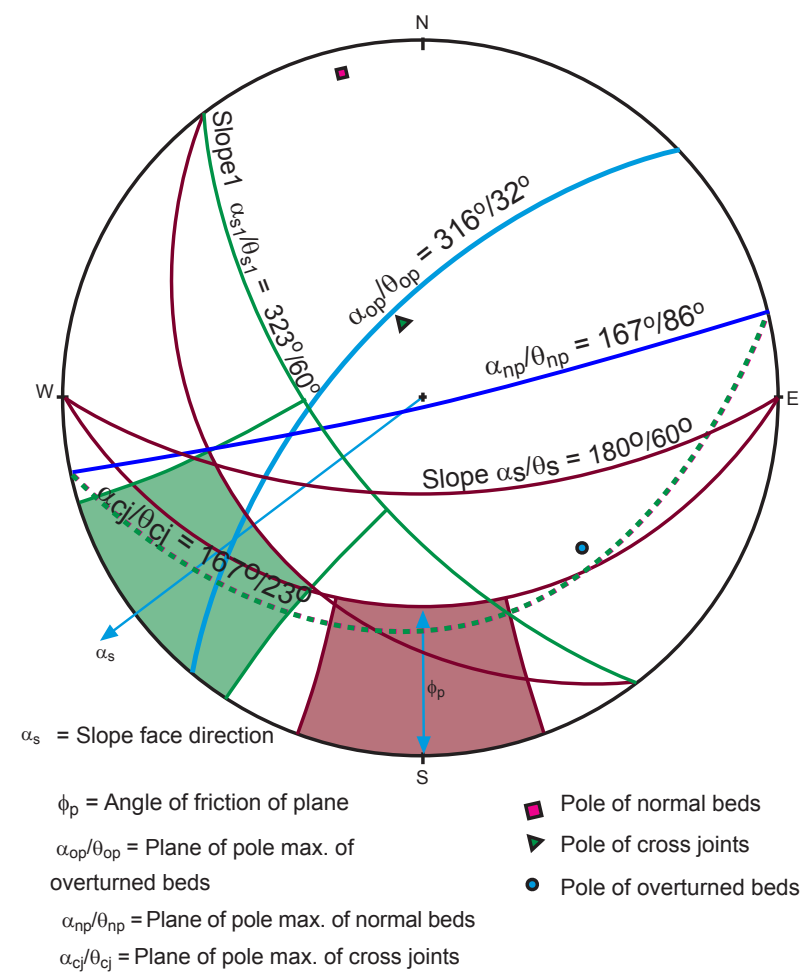

Fig. 8 Stereographic projection of poles of discontinuities from the landslide area for kinematic analysis.

\section{Plane failure}

Kinematic analysis of plane failure for the multi-faced slope is performed. The analysis indicates that there is no possibility of plane failure as the plane of discontinuity does not lie within the criteria of Markland (1972), or the shaded area of Fig. 10.

\section{CONCLUSIONS}

A huge landslide has been identified on the right bank of the Malekhu River. This Malekhu Landslide is a complex type of landslide experiencing different modes of failure. Two important modes of failure are toppling and wedge failures. The direction of toppling is $167^{\circ}$ and slight rotation of dip direction in counter clockwise rotation of $31^{\circ}$ degrees has been recorded from back analysis of the toppled rock mass. The total amount of rotation of average beds from the normal to the overturned situation is $36^{\circ}$. However, the kinematic analysis shows that the toppled beds could have slided because of generation of potential line of intersection between the normal and the overturned beds. There is no possiblity of further toppling and plane failure along discontinuities. But wedge failure may actively occur and the remnant

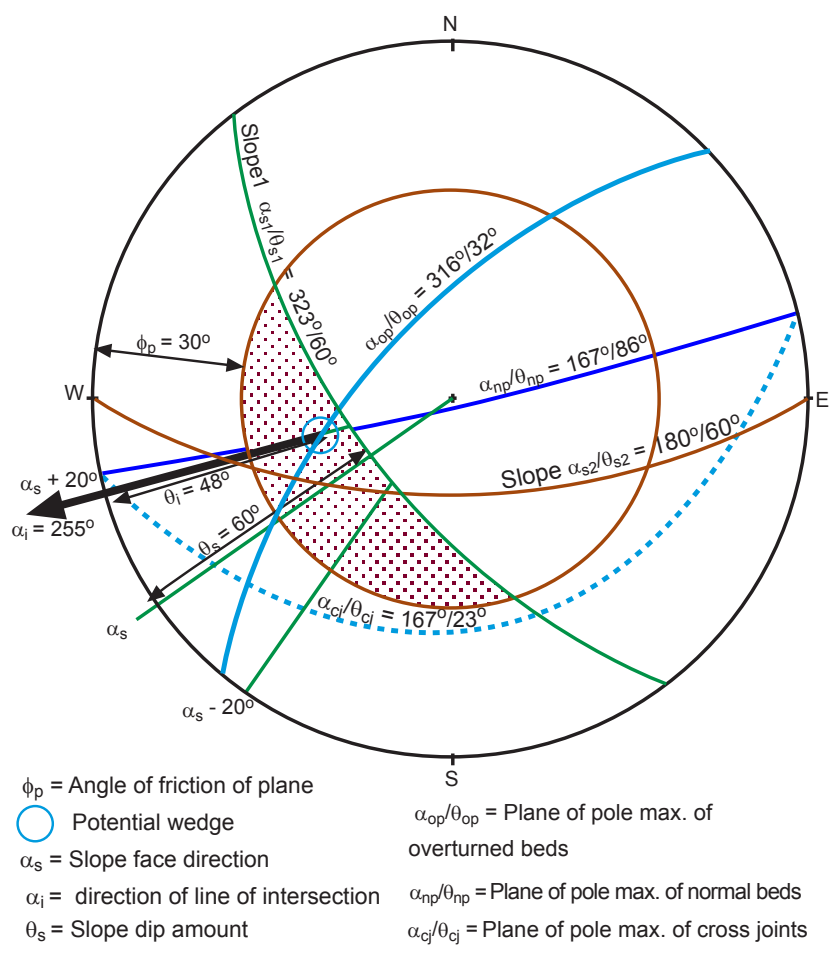

Fig. 9 Stereographic projection of discontinuities from the landslide area for wedge failure kinematics for a multifaced slope. Dark arrow indicates possibility of wedge failure. 


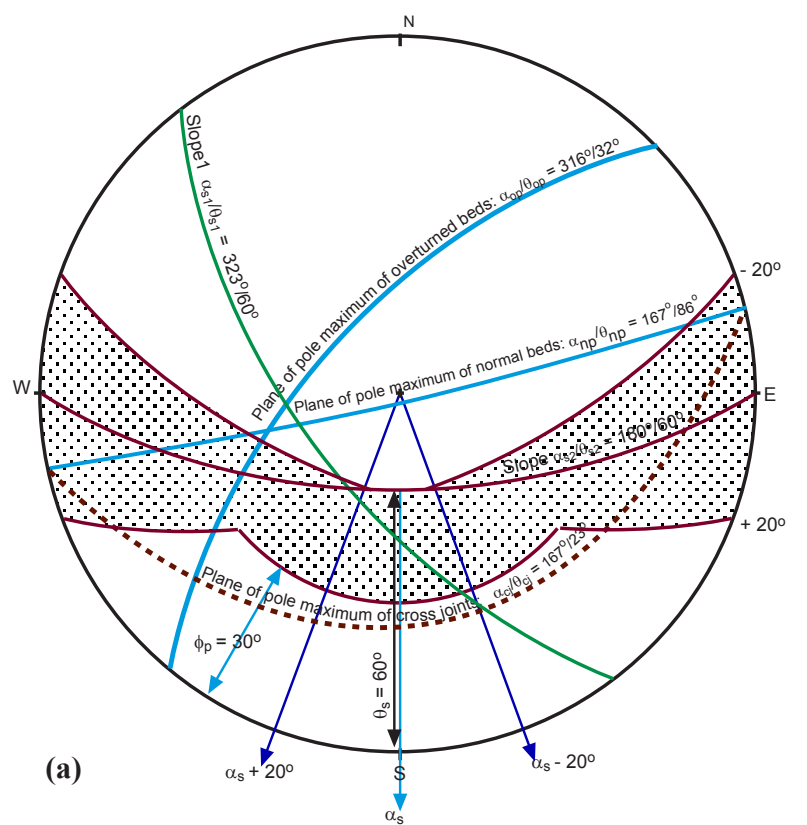

$\begin{aligned} \phi_{p} & =\text { Angle of friction of plane } \\ \alpha_{\mathrm{S}} & =\text { Slope face direction } \\ \theta_{\mathrm{S}} & =\text { Slope dip amount }\end{aligned}$

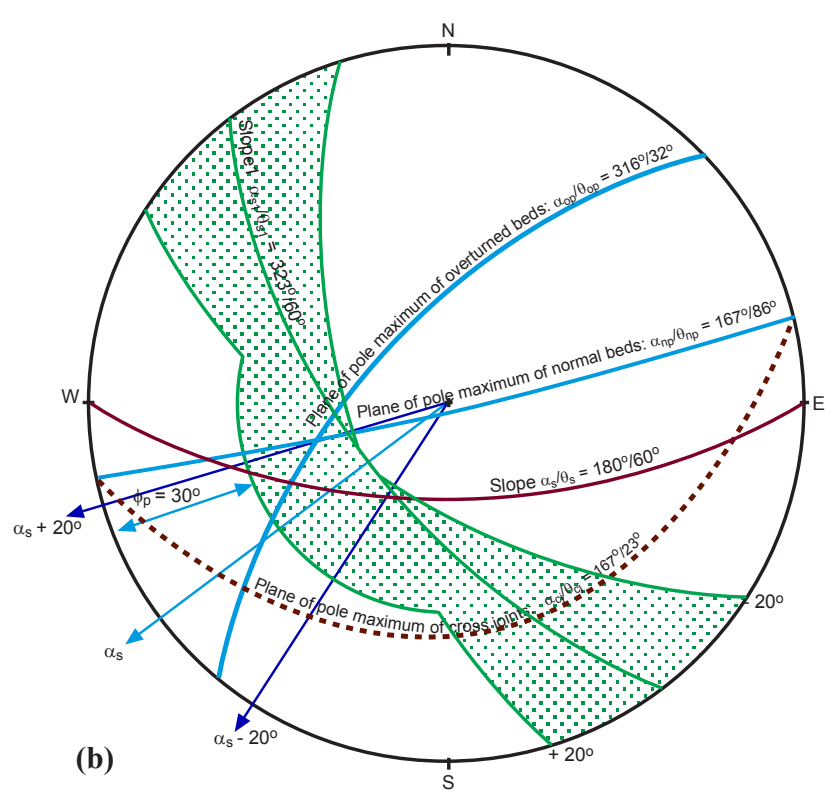

$\theta_{\mathrm{op}}=$ Overturned plane dip amount

$\alpha_{\mathrm{cj}}=$ Cross joint dip direction

$\theta_{\mathrm{cj}}=$ Cross joint dip amount

Fig. 10 Stereographic projection of discontinuities from the landslide area showing plane failure kinematics for multifaced slope: (a) Kinematics for the south-facing slope, and (b) Kinematics for the south-west-facing slope.

of the toppled blocks may further slide downslope causing the road structure, one in the crown and the other in the toe to be under risk. Toe cutting by the Malekhu River, during flood may affect lateral support of the slope and aggravate the sliding phenomenon.

\section{ACKNOWLEDGEMENTS}

Authors are thankful to University Grant Commission (UGC) for providing a partial support to carry out work. Authors also thank Central Department of Geology for providing necessary facilities.

\section{REFERENCES}

Aydan, O. and Amini, M., 2009. An experimental study on rock slopes against flexural toppling failure under dynamic loading and some theoretical considerations for its stability analysis. Joun. school of marine sci. and technology, Tokai Univ., v. 7, no. 2, pp. 25-40.

Goodman, R.E.,1989. Introduction to rock mechanics.h John Wily \& Sons.

Goodman, R.E. and Bray, J.W. (1976). Toppling of rock slopes.h ASCE Specialty Conference on Rock Engineering for Foundations and Slopes, Vol. 2, PP. 201-234.
Majdi, A. and Amini, M., 2011. Flexural Toppling Failure in Rock Slopes: From Theory to Applications. I.J.M.G.E., University of Tehran, Vol. 45, No. 1, December 2011, PP. 21-32.

Markland, J.T., 1972. A useful technique for estimating the stability of rock slopes when the rigid wedge sliding type of failure is expected. Imp. Coll. Rock Mech. Res. Rep. 19, pp. 10.

Stöcklin, J., 1981. Geology of Nepal and its regional Frame. Journal of the Geological Society of London, 137, pp. $1-34$. http://dx.doi.org/10.1144/gsjgs.137.1.0001

Stöcklin, J., Bhattarai, K.D., 1977. Geology of the Kathmandu area and central Mahabharat range, Nepal Himalaya. Report of Department of Mines and Geology/ UNDP ( u n p ublished), $\quad 86 \mathrm{p}$. http://dx.doi.org/10.1144/gsjgs.137.1.0001

Tamrakar, N.K. and Yokota, S., 2008. Types and processes of slope movements along East-West Highway, Surai Khola area, Mid-Western Nepal Sub-Himalaya. Bull. Dept. Geol., Tribhuvan University, v. 11, pp. 1-4. http://dx.doi.org/10.3126/bdg.v11i0.1427

Tamrakar, N. K., Yokota, S. and Osaka, O., 1999. A toppled structure with sliding in the Siwalik Hills, midwestern Nepal. Engineering Geology, v. 64, pp. 339-350. http://dx.doi.org/10.1016/S0013-7952(01)00095-3 